\title{
The Phenomenon of Boarding School and Its Mathematics Learning
}

\author{
Aan Hendrayana ${ }^{1}$, Anwar Mutaqin ${ }^{2}$, Syamsuri $^{3}$ \\ 1,2,3 Universitas Sultan Ageng Tirtayasa \\ ${ }^{1}$ Correspondence Address; anwar_mutaqin@untirta.ac.id
}

\begin{abstract}
The phenomenon of boarding school has evolved since the 1990s. In addition to having advantages, the school also has barriers in the learning process. Therefore, the need to explore some information directly related to the reasons why boarding school is developed, students' life in school together and the learning process that occurred. The research method is used a qualitative approach. Schools in this study are limited to Islamic boarding schools at junior high school level in grade VII. The research procedure is undertaken to find the phenomenon of research subjects that occurred at boarding schools. The validity of data in this research uses source and method triangulation techniques, namely by checking phenomena obtained from observations, interviews with parents, interviews with students, interviews with teachers, and interviews with teachers dormitories. The general conclusion regarding Islamic-based boarding schools is that the school has become the choice of parents in educating their children to gain abilities in the religious and academic fields. In mathematics learning, the teachers prefer direct approach learning rather than indirect learning, and also most of them do not use a lesson plan as teaching guides. Therefore, the school must be able to choose and apply a learning approach oriented to the conditions of diversity that occur in boarding schools so that students have no difficulty in receiving the subject matter.
\end{abstract}

Keywords: boarding school; mathematics learning; phenomenon of boarding school.

\section{INTRODUCTION}

Boarding schools treat all students to study and live in the same location. Meanwhile, school and dormitory activities are integrated and managed by the school. The phenomenon of boarding schools has grown since the 1990s. In principle, this model school isn't a new form in Indonesia. In practice this model of education has been carried out by pesantren, it could be that the education of this model can be historically older than the normal schools that students enter in the morning and go home in the afternoon or evening (Permani, 2011). The students that live in a building are led by a teacher called the guardian of the dormitory. The guardian has the authority to control the activities of students when outside the learning class. In this position, the guardian of the dormitory acts like the parents of students.

Currently, boarding schools have become the people's choice because they have many advantages over ordinary schools. According to Setiawan (2013), several advantages in boarding schools, namely: (1) Student association supervision is easier, (2) Guidance and service to students can be more optimized, (3) Daily activities can form independence and maturity, (4) Efficiency in educating a children, (5) Integration of boarding schools makes it effective in transportation, (6) Gathering all students in the same residence allows them to be active interaction, (7) Moral cultivation in the form of moral values and worship can be more intensively given to students, (8) Coordination and communication of fellow students, fellow teachers, and between teachers and students, more effective, and (9) Academic development, for students, is more optimal. 
Based on these advantages, it is not unusual for boarding schools to be the parents' choice for their children. However, it should be noted that despite the many advantages that boarding schools have there is the potential to cause some disadvantages that students with other students have a great variety. Diversity can be in the form of social background, culture, level of intelligence, language, learning style, academic ability, and gender separation. This condition requires very high adaptability (Bass, 2014). Therefore, students' ability to understand diversity is important.

The problem of student diversity occurs in all schools. However, the problem of diversity that can create major problems in boarding schools. This happened because Islamic boarding schools demanded to discipline their students to get used to relatively similar habits and facilities. Meanwhile, students come from different family backgrounds, facilities, and habits so that this can cause shock that tends to be negative, especially for new students entering. This can give a negative impact on students, such as: not focusing on learning, being sick, and even choosing to change schools, especially for students who are not strong metal ready to be in boarding schools and do not get strong encouragement from the family (Düşek \& Ayhan, 2014).

Furthermore, boarding schools demand high adaptability. In this school, students must accept a new culture, namely a dormitory as a substitute for a family culture which has been a part of life, perhaps from birth. Students who are used to getting help with learning through parents will experience difficult times. As a result, homesick will dominate in boarding schools. Whereas, excessive homesickness can result in the low achievement of children's cognitive abilities (Fisher, 1985). For this reason, the teacher must have a good strategy in overcoming this.

Islamic boarding schools are certainly very suitable in character building (Abdurrahman, 2016), so that moral cultivation in the form of moral values and worship can be more intensively given to students. Although the boarding school focuses on Islamic values, schools continue to provide general subject matter. Moreover, boarding school students must take the final examination, for example the final national examination. Giving general material in the form of effective language communication is given to this boarding school (Efrizal, 2012). Gathering all students in the same place of residence allows them to be active interaction and communication. However, for material that is abstract in nature, such as mathematics, there has not been many description of the learning done by students and teachers at the school. Moreover, in the assessment of national examinations, one of the symbols of failure in schools is usually identified with mathematics because it has a high level of difficulty to master it (Susilo, 2004).

Several studies have been conducted related to learning mathematics in boarding schools. Razak (2017) reveals that there is a relationship of initial abilities towards critical thinking skills of mathematics in students at a boarding school. In addition, Aminullah (2013) argues that there are differences in anxiety between middle school regular students and boarding school students. Therefore, mathematics teachers at boarding schools are expected to provide opportunities for students to play an active role so that students are motivated to achieve optimal performance. This is to avoid the atmosphere of students who do not feel the pleasure of learning, learning to just carry out their obligations is often seen because of compulsion (Suherman, 2003). The 
school also needs to optimize counseling services in helping students who have difficulty following the teaching and learning process so that it is expected that students' anxiety gets psychologically good treatment.

Research on boarding school is mostly related to some advantages and disadvantages of boarding school, as well as religious learning. And it seldom reveals general learning phenomena, especially mathematics learning. For this reason, a study of boarding schools, both in terms of dormitory life and learning, is needed to dig deeper into the actual phenomena. This is useful as a consideration for parents and prospective boarding school students to know the description of life and religious learning as well as general lessons that occur in the boarding school. Therefore, this article seeks to uncover phenomena in boarding schools and their learning, especially in mathematics.

\section{THE RESEARCH METHODS}

This study uses a qualitative approach developed by Miles \& Huberman (2000). Qualitative methods are chosen, because of the phenomena to be studied, the data collection process, and the most appropriate analysis to describe the phenomenon in boarding schools. Schools with the same name in this study are limited to Islamic-based boarding schools at junior high school level in class VII from 2003 to 2018.

The procedure of research conducted to find phenomena from the subject of research that occurs in boarding schools. These phenomena are obtained from the results of observations, interviews with parents of students, interviews with students, interviews with teachers, and interviews with teachers as guardians of the dormitory. This activity is to uncover findings at boarding school junior high school. The findings will be explored from the phenomenon of boarding schools in general, the reason parents choose the school and learning general subjects, especially mathematics that occurs in the school.

The school phenomenon is meant to know why boarding schools are becoming popular in education in Indonesia. This phenomenon is obtained through fact-finding through literature and interviews. Literature is taken from the results of research that has been done. Interviews were conducted with parents, teacher as guardian of dormitory, mathematics teachers, and students from Nurul-Fikri Boarding School Middle School, AsSyifa Boarding School, and Darut-Tauhid Boarding School Junior High School.

The validity of data in this research uses source and method triangulation techniques, namely by checking phenomena obtained from observations, interviews with parents, interviews with students, interviews with teachers, and interviews with the teacher as guardian of a dormitory. Any questions asked to students related to their motivation, classroom learning situation and daily life in the dormitory. The questions that were asked to parents are why they decided their children as students boarding school, and also their opinion about a boarding school and learning that take place in it. The questions that were asked to mathematics teacher related to their lesson plan created dan mathematics learning activity in classroom. And any questions asked to teacher as guardian of dormitory related to situation in daily life in the dormitory. In addition to interviews, we also made observations in mathematics learning classroom and in students dormitory. Conformity of data between observation and interview 
results is used as a valid data reference. In addition, the suitability of interviews between parents and teachers is also used as reference for the validity of the data.

\section{THE RESULTS OF THE RESEARCH AND THE DISCUSSION}

The first finding was the establishment of many new boarding schools. As data of search results include: Anyer NFBS Middle School was established in 1999, Assyifa Middle School in Subang was established in 2006, Fajrul Karim Middle School in Serang was established in 2010, DT Middle School in Bandung was established in 2011, and Al-Kahfi Middle School in Sukabumi was established in 1998, and the NF Middle School in Lembang was established in 2010. Nevertheless, unfortunately the researchers did not find a data source that provided the growth of the boarding school every year. Of all the boarding schools mentioned, most of these schools have become the favorite choice of many parents.

His favorite boarding school is evidenced by the entrance examination to limit children to become students at the school. This fact shows that boarding schools are excellent schools because they have attention and concern for the expectations of parents. Also, boarding schools are a favorite because they pay attention to educational services, representative school buildings, adequate school equipment, professional teachers and school staff (Prianto, 2011). This finding is in line with the opinion of Murdopo (2013) which states that the decision to choose a school depends on conformity with the needs of students. Parents argue that boarding schools are schools that are suitable for their children's needs. This is supported by excerpts from interviews of Researcher (R) with Teacher as guardian of the dormitory (GD) in one of the boarding schools.

$\mathrm{R}$ : Excuse me.

GD: Yes, anything, can I help?

$\mathrm{P}$ : I want to ask. Is it really at the time of admission, full class according to quota?

GD: Yes, sir. There are even many children who are rejected ...

The second finding, when many local governments began to eliminate state junior high schools but parents of students instead chose expensive schools. This means that the consideration of money is not the main thing for many parents in sending their children to school. This phenomenon has been confirmed in five parents of students. The result, they argue that the results achieved by students are relatively comparable to the costs incurred. This was revealed from the interview of the Researcher (R) with the students' parents (SP) in one of the boarding schools.

$\mathrm{R} \quad$ : ... why do you choose the boarding school for your children?

SP-1: Look like this ... first, my children can get life independence, second, have better morals, third, is easier in worshiping like prayer does not need to be told again, the fourth, is more responsible, the fifth, children are more mature, what else ...?

R : How about academic ...

SP-1: academically good, doesn't disappoint. Indeed, at the beginning of entry, the child has a complaint with guidance but then there is nothing.

$\mathrm{R}$ : Regarding the cost of school ... How do you compare fees at a boarding school?

SP-1: It costs more than public schools, but I think it's comparable to the results obtained 
$\mathrm{R} \quad:$ Oo ... How is the teacher related?

SP-1: the teacher is more attentive, patient, and focused. Oh yeah, .... other advantages ... child association is more observable can be said of balanced boarding schools in the world and the hereafter

$\mathrm{R}$ : What about the facilities in boarding schools

SP-1: He ... he ... that's the usual, it doesn't need to be discussed because it's the purpose of being included in boarding schools, so that children receive a lot of limitations and aren't too spoiled with facilities at home ...

Similarly, interviews with other students' parents (SP-2).

$\mathrm{R} \quad$ : Regarding costs incurred in boarding schools

SP-2: It's the same, in public schools also the daily allowance is also large. I think there are differences but not significant. Moreover, there are many advantages that our children get after being schooled in boarding schools. However, the most troublesome thing is when the child is sick, his language is ang melang 'once if only spoiled is normal.

$\mathrm{R}$ : Are you responding to the teacher in a boarding school?

SP-2: Almost every teacher must have a good conscience, I'm sure it's good

$\mathrm{R} \quad$ : When compared to public schools

SP-2: I think I'm rather more comfortable with the teacher at the boarding school.

The results of interviews with schools, this condition familiarizes students to live independently. Confirmation was made on the parents of students whether their children were more independent after attending boarding schools, their answers were not different, namely their children were more independent than before.

$\mathrm{R}$ : Introduce I asked for his help briefly to ask the question why you choose boarding schools for the education of your children

SP-3: Initially I just took part in the test, sir ... because many of my friends enrolled their children in boarding schools. However, I asked many friends that their children had gone to boarding schools and some even graduated. From them, I was strengthened to maintain boarding schools.

$\mathrm{R}$ : Then now?

SP-3: I found something new about my child.

$\mathrm{R}$ : What is it?

SP-3: More independent, prayer without having to be told, not spoiled, looks more mature than friends in public schools.

Research on why parents choose boarding schools is done through interviews with some parents using open-ended questions, namely: why did they choose their children to study in boarding schools. The results of interviews with parents of students resulted in twelve reasons. Their reasons include: (1) children have self-regulated life, (2) children have better morals, (3) children are easier to worship, (4) children are more responsible, (5) academic children are better, (6) association children are more monitored, (7) balanced children's education for goals 
in the world and the hereafter, (8) more mature children, (9) expensive costs comparable to student learning outcomes, (10) teachers are more attentive, patient, and focused (11) children fluency in Arabic and English, and (12) children who are good at speaking and speaking in public. Of course this is in line with the research of Sanusi (2012) which revealed that independence in boarding schools starts with simple life management behaviors, such as eating, clearing beds and so on. Even though it is simple, if it is done repeatedly and lived as it is, it will produce great independence. This is the confirmation writer with interviews with boarding school students (SB).

SB-1: Glad to stay here ... I want to go to a rich school like this

R: Why?

SB-1: Challenge and practice

$\mathrm{R}$ : What training?

SB-1: Independence sir

$\mathrm{R}$ : Is there another reason?

SB-1: I can study academically and I don't forget religion

R: Subhanallah ...

$\mathrm{R}$ : Is it enough at this school?

SB-2: I glad to stay here, sir.

$\mathrm{R}$ : That means?

SB-2: You feel like that, sir

$\mathrm{R}$ : Why?

SB-2: My father said that there are many advantages

$\mathrm{R} \quad$ : Do you feel that?

SB-2: Yes

$\mathrm{R}$ : What is that?

SB-2: Can understand a lot of people

$\mathrm{R} \quad$ : Then?

SB-2: People buy into this school and pay again, I think there are many other benefits

$\mathrm{R} \quad$ : I see...

This advantage has made many parents who are very interested in sending their children to boarding schools. To confirm the truth of parents' opinions, the researchers interviewed three guardians of the dormitory as a substitute for parents in boarding schools. As a result, the boarding house guard justifies ten reasons parents choose boarding schools and adds two other reasons, first as a status symbol for parents and both busy parents. Meanwhile, the reasons for the busyness of parents occur include (1) working hours, (2) both parents work, (3) activities for picking up children, (4) parents outside the region or abroad. According to the boarding house guardian, all of these reasons have nothing wrong, although it may seem that the boarding school is a daycare center. Because basically, all parents want their children's success later.

The interview continued with the teacher. The teacher believes that their strengths become teachers in boarding schools, namely: (1) they can monitor student learning activities in the 
classroom and outside the classroom, (2) they can access students at any time, (3) they can condition the child according to the teacher's wishes, (4) they can understand the character of students one by one more deeply, (5) they can carry out congregational prayers and other activities with their children while we are tasked with watching over them. But the teacher revealed the difficulties that arise in boarding schools, namely: (1) limited leisure time, (2) busy with activities at school and outside school, (3) for teachers some schools feel access to learning resources is quite far, (4) trapped in the same daily routine, if you are not good at dealing with it, you will feel bored.

Interviews were also conducted with students in boarding schools. Reasons from children were obtained: (1) parents want them to boarding schools, (2) the reason their schools are favorite schools, (3) besides academics can study religion, (4) challenge, and (5) to avoid the environment not conducive to harmful learning and association.

This boarding school is certainly more than implementing a full-day school system. Thus, in boarding schools, this enables the realization of education. In terms of the goals and objectives of education which cover the cognitive, affective and psychomotor domains in an optimal manner (Baharun \& Alawiyah, 2018). In addition, schools do have to pay attention to patterns of interaction between teachers and their students, especially in the learning process (Widyastuti, 2016). This is the consideration of the parents so they do not object to the financial obligations incurred.

The third finding, there is gender separation. In boarding school, classrooms and male and female dormitories are separated. However, there are also only separated dormitories while at the same time in class are combined in one class, there are men and women while limiting male and female interactions. This condition raises contradictions in a social reality where most schools mix male and female students. The results of the confirmation with the school that gender segregation is done to minimize the interaction of men and women for religious reasons. Whereas boarding schools that combine men and women in one class by analogy with congregational prayers may consist of male and female worshipers.

Many factors must be considered in school learning, especially in learning mathematics, including willingness, ability, and certain intelligence, teacher readiness, student readiness, curriculum, and presentation methods. Factors that are not less important are student gender factors (Amir, 2013). In learning, male and female students have differences in the process of answering questions (Asmaningtias, 2016; Anggoro, 2016). However, this separation can optimize learning, because mathematics learning in a single-gender class has many advantages compared to mixed classes. These advantages include creating an effective classroom atmosphere to be active in responding to learning material so that when something is not understood, it can be directly asked the teacher in question without hesitation (Ismah \& Febriana, 2017).

The fourth finding is that children are very busy in boarding schools. At this school, the child is awakened at 3:00 a.m. for evening prayer, dzikir, and reading the Qur'an. Then continue the morning prayer, tilawah, and recitation in small groups until 05.00. After those preparations for school, such as bathing, breakfast, and dressing until 6.45. Students are at school until 16:50. After that, until near sunset, they do bathing and eating activities. Followed by prayer and 
recitation until 8:00 p.m. At the end they were given the opportunity to study until 9:00 p.m. and after that they slept, it is certainly not easy to condition children to enter the boarding school with a series of programs that are so dense In this school, it's as if children's activities are monitored 24 hours as a learning activity. For children who often get time and entertainment at home, it is not easy to accept this condition. The interview was conducted to the principal, he argued that with high student activity the student's performance would be higher. The opinion of the principal is justified by the guardian of the hostel on the grounds that when students are given a lot of free time instead of learning students but tend to play. But when this is confirmed to students, they agree that there needs to be time for refreshing, including playing. The busy activities of children in boarding schools caused students to feel exhausted so that in some activities such as dhikr after prayer, classroom learning was found in students who fell asleep. Another result experienced by students is irregular eating patterns. Students feel they have not had time to eat because the change in previous activities to the next activity is felt very fast. Next, the researcher confirmed to the teacher as guardian of the dormitory (GD) and Principal of the Boarding School (PBS).

GD: ... Oh yeah, for some parents it is aimed at entrusting their children because at home it is difficult to be educated, especially related to worship and discipline.

$\mathrm{R}$ : There are others?

GD: It doesn't seem like there ...

$\mathrm{R}$ : It is a child complaint that states that the schedule at the boarding school is very crowded, sir?

GD: that's normal, the reason for a child who just entered. Later too, after they have been here for one year they will enjoy the rhythm of activities at school. Later, they will feel nostalgic when there is a long holiday. And there are some of them who came before the time of entry, even though it wasn't far away. Try asking those who have been around for a long time, there must be many answers that say they are bored because there aren't many friends.

PBS: What is that?

$\mathrm{R}$ : There are complaints from students that the schedule of activities at the school is very crowded so that they are not enough time to study at the hostel

PBS : Hehe ... class VII ?

R : Right, stadz.

PBS : Ordinary for VII, later you will get used to it too. High activity will make high performance.

$\mathrm{R} \quad: \mathrm{Oh}$, is that?

PBS : Right, just look after one year here or at least one semester

$\mathrm{R} \quad$ : Need habituation, right?

PBS: Right

The fifth finding, new students have a high level of permission in learning. After observing for one month in the class of women and men, there are always students who are permitted every day, either by reason of illness by staying in the dormitory or being sick so they 
need to leave the dormitory or family reasons. Meanwhile, in the female class, this condition often leads to school transfer whereas in men's class it does not occur. For the record, in the research class, 4 female students who changed schools before the end of the first semester and this phenomenon also appeared to occur in two other boarding schools. This condition shows that the potential to move to boarding schools is high enough to require attention from the school.

To get answers to why they did much permission in learning, researchers confirmed to several students and guardians of the dormitory. Confirmation on students is done, with the question of why they are licensed. Student answers include: a busy schedule, incomplete facilities, a variety of unsatisfactory services, and related to discipline. Confirmation is done at the boarding house guardian. According to the guardian of the hostel, usually the permits are a lot because they are shocked by the density of activities. Apart from that, students have not been used to arranging schedules because they find friends hanging out for 24 hours. According to the boarding house guardian, the incident is common in 7 th graders and grade 8 they will get used to life in boarding schools. To confirm the confidence of the information from the guardian of the dormitory, the research was conducted in class 8. As a result, in this class, the level of the permission was not as much as in class 7 . The results of this phenomenon were confirmed in the boarding house at Nurul-Fikri Middle School. form of the inability of students to live in boarding schools.

$\mathrm{R}$ : Assalamu'alikum. Yeah, where are you going?

Students together: On sick and pack permission ...

$\mathrm{R}$ : How come I'm compact?

SB-3: On pack tiredness, so it hurts

$\mathrm{R}$ : Then what is permitted?

SB-4: Just look for reasons, even though you want to take a break at home

SB-5: Yes sir, I will also want permission later ... after here there is no rest. Tight schedules, solid activities, and facilities like that

Students together: Yes right, sir

P: Oh ... oh ... I already forgot about the problem that was sick and permission. We just start learning.

One phenomenon that occurs in schools is the high frequency of student permission. This is a form of the inability of students to live in boarding schools. The condition of students like this can result in homesickness (longing for the conditions at home) that can be excessive for students. Homesick symptoms can be sick and ask to leave school (Fisher, Frazer, \& Murray, 1984). As a result of that, many students in the first year at school have this problem in learning in the classroom and not complete in doing the task. The results of observations conducted at three boarding schools in western Java, there are findings that there are always students who change schools and the intensity of student permission is very high because of illness in the first semester of each year. Therefore, the need for prospective student mental anticipation is carried out by parents so that their children are mentally ready to live their lives in boarding schools.

The sixth finding, the curriculum used still KTSP (Education Unit Level Curriculum). The reason for the school policy is that they still use KTSP because the teachers at the school 
have not received the 2013 curriculum training from the Bandung City Service or other parties. When confirmed to the teacher assigned by the school to contact the city education office, the answer is to wait for their turn from the department. At the time this research was conducted, teacher training related to the 2013 curriculum was still limited to certain schools in this case the priority was in government-owned schools. This phenomenon shows that active communication from boarding schools with stakeholders, in this case, the city education office, has not gone well. As a result of confirmation at two other boarding schools, this condition turned out to be a little different. This phenomenon also shows that the policy on the government in government schools with non-government schools seems to have little difference. According to the official, this condition is not merely a mistake of service because private schools often do not respond quickly to official requests.

From the teacher's side, they often feel that there is a top priority of the school not belonging to the government, namely the implementation of learning takes precedence with the confirmation of the results of the confirmation by the Principal. The application of KTSP can be interpreted as giving the widest possible autonomy to schools in managing schools, including innovation in curriculum development and learning models through KTSP (Asriati, 2010; Firmansyah, 2007). This is quite complex if observed, the point is that the government's authority over non-state schools is not as strong as that of government-owned schools. For that, the government needs to pay attention to this phenomenon and find the right solution so that the principle of education that education for all levels and circles (education for all) can be fulfilled properly.

The seventh finding, fewer hours of mathematics learning. At this school, there are only two meetings every week. The results of the confirmation with the deputy headmaster of the curriculum section were carried out because it accommodated the campus schedule. For public schools, the minimum math schedule is three meetings a week. As a result of the smaller number of meetings, the learning plan must be compacted. This phenomenon is not the same as other boarding schools because it depends on the orientation of the boarding school. Middle School DT is more oriented towards memorizing Al-Qur'an while SMP NF is more on science achievement.

The eighth finding, the lesson schedule that is next to prayer times is often problematic. Lessons that approach prayer times are often disturbed by the mood of the students' desire to be present on time. This happens because students prioritize prayers on time. The choice of prayer is a priority because if they do not attend on time it will result in acceptance of sanctions from discipline enforcement teachers. As a result of that, the lesson hours before prayer time disrupt the concentration of student learning and to fulfill this the lesson time becomes shorter. This phenomenon is not different for other boarding schools after being confirmed by other school teachers. The following are excerpts of interviews with mathematics teachers (GM) boarding schools.

$\mathrm{R} \quad$ : Many children are nervous?

GM-1: Yes because the lesson time is tight with Friday time.

$\mathrm{R} \quad$ : That's right ... 
GM-1: They will get a disciplinary commission if they are late for prayer. While prayer times are very dynamic, different from the lesson schedule

$\mathrm{R} \quad$ : Is that reasonable, ... And that also makes mothers always prefer direct learning?

GM-1: Hehe ... How do you do it, sir ... Time to study a little, lesson time is a little, and sometimes cut up by dynamic time (meaning prayer)

$\mathrm{R}$ : Oh yeah....

GM-1: Yes, sir

$\mathrm{R}$ : I have been chatting with Mr. GM-2, there are many advantages for teachers in boarding schools

GM-1: What is it, sir?

$\mathrm{R} \quad$ : He said that in boarding schools teachers can see the development of student learning in the classroom also outside the classroom, teachers can access students at any time because they live here, and the teacher can condition students according to the teacher's wishes. What is your mother's opinion?

GM-1: Right, only when students have an academic schedule, we are not easy to control students $\mathrm{R} \quad$ : Why is that Mrs.?

GM-1: There are sanctions for students if they do not follow it. Does Mr. GM-2 reveal the shortcomings?

$\mathrm{R} \quad$ : He said that the teacher has limited free time, the teacher is busy with activities at school and outside the school, the teacher feels that access to learning resources is quite far or not quite well facilitated by the government. In terms of facilitating the government, for example teachers in this school have not received 2013 curriculum training, compared to public schools

GM-1: Right

In the ninth finding, teachers prefer direct approach learning rather than indirect approach learning. This phenomenon was concluded after observing three mathematics teachers during a month. The results of the confirmation to the teachers, this choice is the influence of the previous phenomenon. According to them, indirect approach learning is a reasonable choice for mathematics teachers with the conditions that develop in boarding schools. This is in accordance with the advantages of direct learning and teacher interpersonal communication (Usman, 2015). As a result of that, learning mathematics in boarding schools is more about the process of transforming information from teacher to student rather than constructing knowledge in students.

$\mathrm{R} \quad$ : in two lessons, you hold indirect learning, right?

GM-1: Right

$\mathrm{R} \quad$ : How is your opinion?

GM-1: Preparation of heaters takes a lot of time and also requires a lot of time to learn. Among other things, there is still a lot of material that needs to be achieved

$\mathrm{R} \quad$ : So?

GM-1: I think, direct learning seems to be more efficient and quite effective.

$\mathrm{R}$ : According to you, what are the advantages of teachers in boarding schools for their students 
GM-1: We can see the development of student learning in the classroom also outside the classroom, we can access students at any time because they live here, and we can condition students as we wish.

$\mathrm{R} \quad$ : What are the advantages, sir, if there are shortcomings?

GM-1: First, a little of free time. Second, busy with activities at school and outside school. Third, we feel that access to learning resources is far enough or not facilitated properly by the government

$\mathrm{R}$ : Does it mean that it is not properly facilitated by the government?

GM-1: 2013 curriculum case, for example.

$\mathrm{R} \quad$ : Why is that?

GM-1: For many teachers in public schools, many teachers have been facilitated for training and workshops but until now we have not offered it.

$\mathrm{R} \quad$ : I see ... yeah ...

In the tenth finding, the teacher did not use a lesson plan as a teaching guide. As for some teachers who use the lesson plan as a guide by modifying adjusting the number of hours less so that the lesson plan only contains substantial material. This phenomenon arises when students are asked questions about their understanding of what a variable is. This question is very easy, but the facts obtained are only two students who answered correctly. When asked to students why they fill in like that, they answer $\mathrm{x}, \mathrm{xy}, \mathrm{y}$ and so on are variables. Then this was confirmed by the teacher who had taught them. The teacher answers that students may forget. To look for the next answer, a search of the student handbook is conducted, saying that the student handbook does not explicitly list what the variable is. To confirm this, the researcher conducted observations during a month (approximately 8 meetings). As a result of observation, two teachers who used to teach first grade did not use lesson plans as a teaching guide but textbooks from publishers selected by the school as their teaching guide. This finding is in line with Kartowagiran (2011) and Retnawati (2015) which states that books become a determinant of teacher teaching quality and the quality of students' abilities. When asked by the two teachers, why they did not use a lesson plan, the answer was that it was not flexible and troublesome with the conditions for setting schedules in schools that made the lesson plan not realized properly.

In the eleventh finding, several students claimed to have never received a repeat test as bad as this school. The results of interviews with the students that they did not have a free opportunity to study because of the overcrowding of study time. Then, they also reasoned that they did not find the person who was asked for help asking about the material taught in the class except for the results of their colleagues. Confirmation is done at the dormitory guardian, according to the dormitory guardian in each room, there is one senior student assigned to assist students in adapting to the dormitory environment both academically and non-academically (boarding). Confirmation is done again with students, answers from students that their seniors cannot all help to answer their mathematical problems. Then the students added, they were dominantly helped by their classmates who were more understanding.

$\mathrm{R}$ : Regarding mathematics learning, what are the children's complaints that often appear in learning

GM-3: Usually it complains with study time for many activities 
$\mathrm{R} \quad$ : Apart from that?

GM-3: Learning assistance

$\mathrm{R} \quad$ : Right, there is a classmate

GM-3: Not all children can adapt quickly to their seniors and not all seniors can answer the problems of their younger siblings

$\mathrm{R} \quad$ : In class, do you prefer direct or indirect learning?

GM-3: How about it ... immediately it seems to be due to time efficiency and in my opinion effective too

$\mathrm{R}$ : What about learning theories that develop

GM-3: Hehe ... that's a theory. Even so, I still condition that learning is designed so students can construct knowledge themselves. However, if they are in trouble then I will give the answer, yes ... because consider a limited learning time.

$\mathrm{R}$ : There is a result of my chat with Mrs. GM-1 and Mr. GM-2, there are many advantages and disadvantages to teachers in boarding schools

GM-3: Oh, so, whatever I want to know?

$\mathrm{R}$ : The advantages, the teacher can see the development of student learning in the classroom also outside the classroom, teachers can access students at any time because they live here, and the teacher can condition students according to the teacher's wishes. How are you, something needs to be added, corrected, or deleted?

GM-3: Enough, even if there are additions, there are many additional tasks besides teaching assignments

$\mathrm{R} \quad$ : For example?

GM-3: Mentoring children outside working hours and I think they lack? Then the disadvantage according to Mrs. GM-1 and Mr. GM-2?

$\mathrm{R} \quad$ : Weaknesses, teachers have limited free time, teachers are busy with activities at school and outside of school, teachers feel access to learning resources is quite far or not sufficiently well facilitated by the government. In terms of facilitating the government, for example teachers in this school have not received 2013 curriculum training, compared to public schools. Do you agree?

GM-3: I agree and add to the shortcomings

$\mathrm{R} \quad$ : Oh, that's enough ... Oh yeah, the kids have come in already. Sorry to bother you, thank you very much.

GM-3: You are welcome

Students in boarding schools will present several different learning problems with students in public schools. First, the application of learning habits and facilities that tend to be the same will raise problems in learning skills, especially mathematics (NCTM, 2000). Secondly, many students are accustomed to collaborating with colleagues who are of different gender, while in gender boarding school students are separated for religious reasons and there is an impression of female gender dominance. Third, some children are used to indirect learning, some are used to direct learning. Fourth, some children with certain mathematical initial abilities have a complete scheme, some do not. Finally, some children usually learn with certain learning styles that require different facilities and approaches but in boarding schools their tendency to be treated equally both in class and outside the classroom. 
Furthermore, general material learning, especially mathematics, the problem of mathematics learning of students in boarding schools need to be considered and the solutions obtained by schools, especially by teachers. If not noticed, students will continue to accumulate learning difficulties. Learning difficulties will lead to poor self-perception. This poor perception can lead to academic and non-academic problems. Apart from that, learning difficulties not only result in mere learning achievement but also on social relations (Octyvera, Siswati, \& Sawitri, 2010). Therefore, guidance is needed with a multicultural approach (Bunu, 2016). With this approach, it is expected to make the learning atmosphere more meaningful.

If the school has not been able to create a conducive learning environment, it will make students become discouraged with two consequences, namely leaving school inaccurately or not achieving the expected competence at the end of the study period, for example not passing the National Examination. In the end, parents will sue for school because the education and coaching role of students is almost all left to boarding schools. For this reason, the teacher must be able to choose and apply a learning approach oriented to the conditions of diversity that occur in boarding schools so that students have no difficulty in receiving the subject matter.

In boarding schools, one of the common learning-material, especially mathematics, in overcoming it is necessary to have an understanding of culture in mathematics (Kinard \& Kozulin, 2008). In mathematics, the diversity of cultural backgrounds should not be an obstacle for students because mathematics has its own culture and tends not to differ much even though different cultures. For this reason, the teacher should be able to deliver that they have the same culture in mathematics. That culture, namely: language, psychological aids, and strategies (Kinard \& Kozulin, 2008). By approaching similarities in culture, students are expected to have no difficulty in accepting the concepts and development of mathematics.

\section{CONCLUSION AND SUGGESTION}

The general conclusion regarding Islamic-based boarding schools is that the school has become the choice of parents in educating their children to gain abilities in the religious and academic fields. This is evidenced by many phenomena that reinforce that boarding schools have many advantages over public schools. Related to the phenomenon of Islamic-based boarding schools, namely: (1) there have been many new boarding schools established, (2) parents of students instead choose paid schools even though the government has made many free facilities in public schools, (3) male and female classes separated, (4) very busy children.

The reasons for parents choosing boarding schools for their children's education include: (1) children have self-regulated life skill, (2) children have better morals, (3) children are easier to worship, (4) children are more responsible, (5) children's academics are better, (6) child interaction is more monitored, (7) balanced world and hereafter, and (8) more mature children, and (9) expensive costs are proportional to results, and (10) teachers are more attentive, patient, and focus, (11) children master Arabic and English, and (12) children are good at public speaking.

Additional reasons from the boarding house guardian, namely: first as a status symbol for parents and both busy parents. Findings of the learning process in Islamic-based boarding schools, namely: (1) the curriculum used still uses KTSP (Education Unit Level Curriculum), 
(2) high level of permission in learning, especially in class VII, (3) more math lessons a little, (4) lesson schedules that are next to prayer times are often problematic, (5) teachers prefer direct approach learning rather than indirect learning, and (6) teachers do not use a lesson plan as teaching guides. To that end, the school must be able to choose and apply a learning approach oriented to the conditions of diversity that occur in boarding schools so that students have no difficulty in receiving the subject matter.

The advantages of boarding schools that students live together have not been optimized in general subject learning, especially in mathematics. Thus the suggestion of this study is the need for innovation in mathematics learning that is different from ordinary schools. The learning innovation is more emphasized on how optimizing the time togetherness of students in the school.

\section{REFERENCES}

Abdurrahman, N. H. (2016). Character education in islamic boarding school-based SMA Amanah. Jurnal Pendidikan Islam, 2(2), 287-305. https://doi.org/http://dx.doi.org/10.15575/jpi.v2i2.791

Aminullah, M. A. (2013). Kecemasan antara siswa smp dan santri pondok pesantren. Jurnal Ilmiah Psikologi Terapan, 01(02), 205-215.

Amir, Z. (2013). Perspektif gender dalam pembelajaran matematika. Marwah: Jurnal Perempuan, Agama Dan Jender, 12(1), 14-31. https://doi.org/10.24014/marwah.v12i1.511

Anggoro, B. S. (2016). Analisis persepsi siswa smp terhadap pembelajaran matematika ditinjau dari perbedaan gender dan disposisi berpikir kreatif matematis Bambang. Al-Jabar: Jurnal Pendidikan Matematika, 7(2), 153-166.

Asmaningtias, Y. T. (2016). Kemampuan matematika laki-laki dan perempuan. Madrasah, 1(2), 1-15. https://doi.org/10.18860/jt.v1i2.1840

Asriati, N. (2010). Implementasi KTSP dan kendalanya (Antara harapan dan kenyataan). Jurnal Visi Ilmu Pendidikan, 3(2), 243-256. Retrieved from http://jurnal.untan.ac.id/index.php/jvip/article/view/84/82

Baharun, H., \& Alawiyah, S. (2018). Pendidikan full day school dalam perspektif epistemologi Muhammad 'abid al-jabiri. Potensia : Jurnal Kependidikan Islam, 4(1), 1-22.

Bass, L. R. (2014). Boarding schools and capital benefits: Implications for urban school reform. Journal of Educational Research, 107(1), 16-35. https://doi.org/10.1080/00220671.2012.753855

Bunu, H. Y. (2016). Pemindaian penerapan bimbingan dan konseling dengan pendekatan multikultural di SMA. Cakrawala Pendidikan, XXXV(3), 386-394.

Düşek, G., \& Ayhan, A. B. (2014). A study on problem solving skills of the children from broken family and full parents family attending regional primary boarding school. Procedia - Social and Behavioral Sciences, 152, 137-142. 
https://doi.org/10.1016/j.sbspro.2014.09.170

Efrizal, D. (2012). Improving students' speaking through communicative language teaching method at Mts Ja-alhaq, Sentot Ali Basa Islamic Boarding School of Bengkulu, Indonesia. International Journal of Humanities and Social Science, 2(20), 127-134.

Firmansyah, F. (2007). Implementasi kurikulum tingkat satuan pendidikan (Struktur dan kendalanya). Tadris, 2(1), 134-144.

Fisher, R. (1985). Teaching Children to Think. Cheltenham: Nelson Thornes Ltd.

Fisher, S., Frazer, F., \& Murray, K. (1984). The transition from home to boarding school: A diary-style analysis of the problems and worries of boarding school pupils. Journal of Environmental Psychology, 4, 211-221.

Ismah, I., \& Febriana, T. (2017). Analisis pembelajaran matematika di kelas gender tunggal. In Seminar Nasional Kedua Pendidikan Berkemajuan dan Menggembirakan (The Second Progressive and Fun Education Seminar) (pp. 183-188).

Kartowagiran, B. (2011). Kinerja guru profesional (Guru pasca sertifikasi). Cakrawala Pendidikan, $X X X(3), 463-473$.

Kinard, J. T., \& Kozulin, A. (2008). Rigorous Mathematical Thinking. Cambridge: Cambridge University Press.

Miles, M. B., \& Huberman, M. (2000). Data Management and Analysis Methods. In N. K. Denzin \& Y. S. Lincoln (Eds.), Handbooks of Qualitative Research. London: Sage Publications.

Murdopo, L. (2013). Analisis preferensi siswa dalam memilih sekolah madrasah aliyah di Pulang Pisau. Jurnal Sains Manajemen, I(1), 8-24.

NCTM. (2000). Principles and Standards for School Mathematics. Boston: The National Council of Teachers of Mathematics.

Octyvera, R. M., Siswati, \& Sawitri, D. R. (2010). Hubungan kualitas kehidupan sekolah dengan penyesuaian sosial pada siswa SMA international islamic boarding school republic of Indonesia. Psycho Idea : Jurnal Ilmiah Psikologi, 7(1), 53-64.

Permani, R. (2011). The presence of religious organisations, religious attendance and earnings: Evidence from Indonesia. Journal of Socio-Economics, 40(3), 247-258. https://doi.org/10.1016/j.socec.2011.01.006

Prianto, A. (2011). Faktor-faktor yang mempengaruhi kepuasan orang tua siswa terhadap layanan pendidikan di sekolah (Studi pada sekolah unggulan di kabupaten jombang). Jurnal Aplikasi Manajemen, 9(3), 1061-1074.

Razak, F. (2017). Hubungan kemampuan awal terhadap kemampuan berpikir kritis matematika pada siswa kelas VII SMP Pesantren IMMIM Putri Minasatene. Jurnal Mosharafa, 6(1), $117-128$.

Retnawati, H. (2015). Hambatan guru matematika sekolah menengah pertama dalam 
menerapkan kurikulum baru. Cakrawala Pendidikan, XXXIV(3), 390-403.

Sanusi, U. (2012). Pendidikan kemandirian di pondok pesantren. Jurnal Pendidikan Agama Islam - Ta'lim, 10(2), 123-139.

Setiawan, I. (2013). Pembinaan dan Pengembangan Peserta Didik pada Institusi Pendidikan Berasrama. Smart Writing.

Suherman, E. (2003). Pendekatan konstekstual dalam pembelajaran matematika. Educare, 2(1), $52-57$.

Susilo, F. (2004). Matematika Humanistik. Yogyakarta: Basis.

Usman, F. (2015). Pengaruh komunikasi interpersonal guru terhadap minat belajar pada mata pelajaran matematika siswa kelas VII smp pesantren immim putra makasar. Jurnal Nalar Pendidikan, 3(2), 63-67.

Widyastuti, R. (2016). Pola interaksi guru dan siswa tunanetra SMPLB A Bina Insani Bandar Lampung. Al-Jabar: Jurnal Pendidikan Matematika, 7(2), 257-266. 